\title{
Spatial and temporal variation of Escherichia coli in water and soil with relation to water parameters at the estuary of Karnafuly River, Bangladesh
}

\author{
Md. Wahidul Alam and Mohammad Zafar \\ Institute of Marine Sciences and Fisheries, University of Chittagong, Chittagong-4331, Bangladesh.
}

Accepted 3 December, 2012

\begin{abstract}
This study examined the concentrations of Escherichia coli in soil and water samples, and some physicochemical properties of water collected from the Karnafuly River estuary, Bangladesh during March-June 2012. Among the water parameters, temperature was in the range 26.5 to $32^{\circ} \mathrm{C}$, salinity varied between 0 and $5 \mathrm{ppt}$, pH values ranged from 7.5 to 7.9 and dissolved oxygen (DO) was recorded at concentrations of 2.28 to $2.91 \mathrm{mg} / \mathrm{l}$. The average total $E$. coli were $26 \mathrm{cells} / \mathrm{ml}$ in water, but the sediment contained $96.42 \mathrm{cells} / \mathrm{g}$ of $E$. coli. The population of $E$. coli was always higher in sediment than those that occurred in water among all sampling stations. The growth of $E$. coli were positively correlated $(\mathrm{P}<0.01)$ with water temperature and negatively correlated with salinity, $\mathrm{pH}$ and $\mathrm{DO}$. The data on water quality parameters and occurrence of $E$. coli indicated that water of the Karnafuly estuary is polluted and unhygienic for drinking, even impossible to use for washing purposes without any treatment.
\end{abstract}

Key words: Karnafuly, Escherichia coli, physicochemical, estuary.

\section{INTRODUCTION}

Microbiological impairment of drinking, bathing, irrigation, or recreational waters is commonly monitored using concentrations of fecal indicator bacteria (FIB). Escherichia coli are the FIB commonly used to evaluate the microbiological water quality. The concentration levels of $E$. coli are significantly influenced by various nonpoint sources such as surface runoff, bank soils, recreational activity, and animal excreta (Kim et al., 2007). Bottom sediments have been recognized as a major reservoir of $E$. coli in freshwater environments (Geldreich, 1970). Many studies indicate that sediments can harbor much higher populations of both fecal coliforms and $E$. coli than the overlying water column (Rehmann and Soupir, 2009).

The Karnafuly River estuary is an important estuary in Bangladesh and hydro-biologically it is the place where freshwater from upstream is continuously mixing with saltwater from the Bay of Bengal. Combinations of

\footnotetext{
*Corresponding author. E-mail: wahid.imsf.cu@gmail.com.
}

diverse fluctuating parameters are responsible for occurrences and distribution of different microorganisms in estuarine environment. It is also blessed with estuarine water, sediment, marine resources and varieties of fish species. Besides a lot of industry, fishing boats, vessels or trawlers and container ships are operating along the river hampering the status of water, sediment and fish species therein. Different researchers reported the estuarine environment polluted owing to the continuous discharge of waste material from the industries and sewage of the town. Certainly, pollution of water courses associated with industrial discharge and refuse from human settlements is a global problem (Joy et al., 1990). Everything carried by rivers ultimately goes into oceans through estuaries. The pollutants get dispersed by turbulence, ocean currents and tidal action firstly in the estuary, then concentrated in the food chain components through microbial action or deposited in the bottom sediments (Islam, 1998). People living in the Chittagong city are mostly depending on the Karnafuly River for drinking or other house-hold purposes. Besides, lots of people including a large number of fishermen live on both 


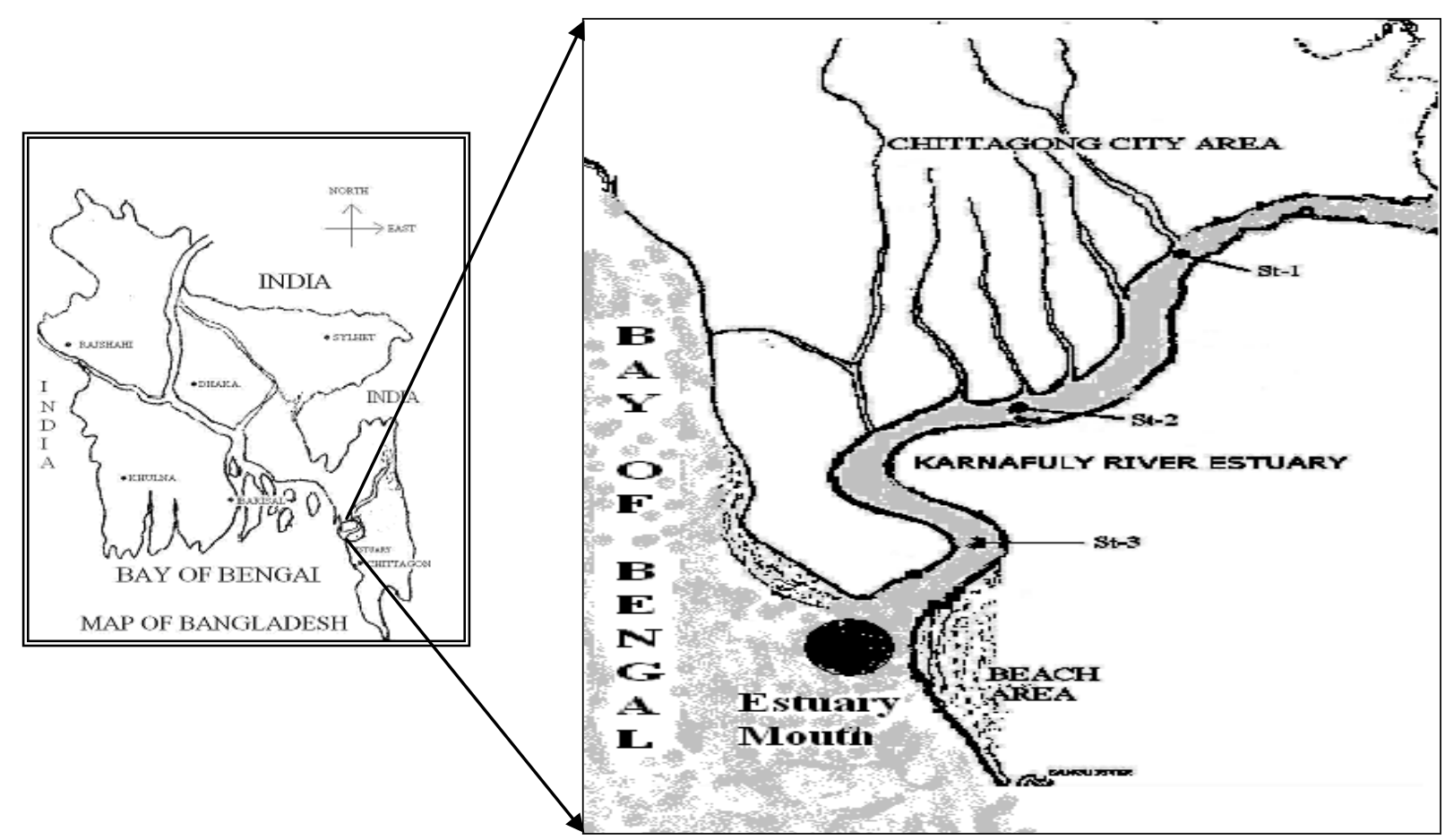

Figure 1. Geographical location of the study area showing different sampling stations.

sides of the river. They use the water for bathing and drinking. They also used sediment and soil for household purpose. Many countries in the world have developed drinking water criteria and standards. Bangladesh developed the first Water Quality Standards in 1976 based on International Drinking Water Standards (WHO, 1984). The Bangladesh standard specification for drinking water (BDS 1240: 1989) was prepared and published by the Bangladesh Standard and Testing Institution (BSTI) for the control of drinking water including bacterial load.

According to World Health Organization (WHO, 1993) and Environment Quality Standard for Bangladesh (EQSB, 1991), the standard value of total load of E. coli for drinking water is nil/ml of water. Different researchers identified different pathogenic bacteria among contaminated fish of the Karnafuly River, but seldom $E$. coli was isolated from water and sediment samples of this area. Considering the importance of water and sediment in everyday life, the present research work aimed to determine the concentrations of $E$. coli in water and soil of Karnafuly River estuary, including their relationship with some water parameters.

\section{MATERIALS AND METHODS}

\section{Description of the study area}

The Karnafuly is the principal river of Chittagong District of Bangladesh. It originates in the Lushai Hills of Mizoram (India), flows through Rangamati and the port city of Chittagong and discharges into the Bay of Bengal near Patenga. The river is flashy and its length is about $131 \mathrm{~km}$. Geographically, this estuary is located between latitude $22^{\circ} 53^{\prime} \mathrm{N}$ and longitude $92^{\circ} 27^{\prime} \mathrm{E}$ and enters the districts of Chittagong from the north eastern side. It travels about 121 miles in zigzag ways to the west and south west side and finally falls on the Bay of Bengal at latitude $22^{\circ} 12^{\prime} \mathrm{N}$ and longitude $91^{\circ} 47^{\prime} \mathrm{E}$ at near Patenga, Chittagong. The average channel depth of the basin at the river estuary is $8 \mathrm{~m}$, although the depth varies greatly in its upstream portion for strong current and siltation.

Geologically, the entire catchment consists of a substratum of tertiary rocks covered with alluvial deposits. The overlying deposits show that it consists of successive layers of mud and sand (Rizbi, 1971). Hydrological parameters that is temperature, salinity, $\mathrm{pH}$, D.O etc. fluctuate seasonally. Three sampling stations (Figure 1) were selected for the present investigation with the basis of different types of pollution. The first sampling station (St-1) located near Chaktai canal (most polluted canal of Bangladesh), receives heavy discharges from different domestic and industrial sources to the estuary. The second sampling station (St-2) is located at the middle portion of the River, where small city canal falls into the river and carry industrial and city wastes. The third sampling station (St3 ) is located at the mouth of the estuary and receives discharges composed of different kinds of city wastes through a canal which ultimately falls into the estuary.

\section{Data collection and analysis}

This work was carried out from March to June 2012. Water and soil samples were collected from three stations of the Karnafuly River estuary during this study period. In situ measurement of water temperature was measured with a centigrade thermometer while water $\mathrm{pH}$ and salinity were measured by pen $\mathrm{pH}$ meter and 


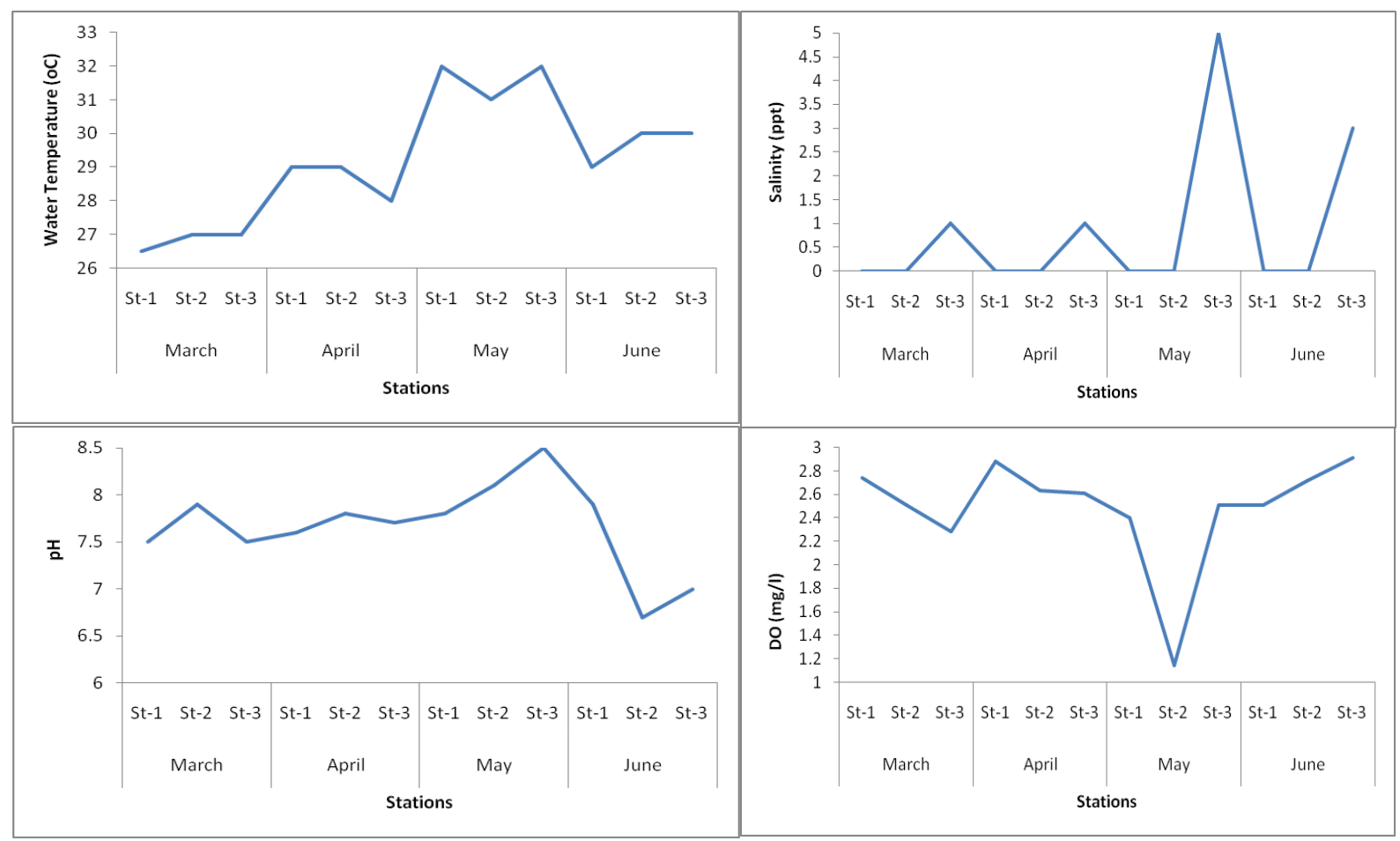

Figure 2. Physicochemical parameters of Karnafuly River at different stations in different months.

refractometer respectively. Dissolved Oxygen (DO) concentration was measured in the laboratory by following standard method (APHA, 1976). Collected water and soil samples were preserved and microbial analysis was conducted in the laboratory to identify $E$. coli in water and soil of the Karnafuly Estuary. E. coli of water and soil were identified by standard plate count (SPC) techniques (APHA, 1976). SPC was conducted by making serial dilution, plating and total plate count by pour plate techniques. In case of water, $1 \mathrm{ml}$ of water sample was transferred with a sterile pipette to a sterile screw capped vial containing $9 \mathrm{ml}$ of distilled water and the vial was shaken thoroughly. The sample was made to give $1: 10$ or $10^{-1}$. In case of soil, $1 \mathrm{~g}$ of soil sample was weighted by weight meter and then transferred to a sterile screw capped vial containing $9 \mathrm{ml}$ of distilled water and then the vial was shaken thoroughly.

The sample was made to give $1: 10$ or $10^{-1}$. Each dilution was plated by sterile pipette with $1 \mathrm{ml}$ of dilution into a Petri dish and the respective sterile melted media were poured into the plates. The plates were rotated by hand, a minimum of 5 times clockwise and 5 times in the anticlockwise direction and several times crosswise for equal distribution of the media. After solidifying the media the plates were inverted. Then the plates were incubated at room temperature. Levin's Eosin Methylene Blue (EMB) agar media were used for identification of the quantity of total $E$. coli population. Triplicate plates of each dilution were prepared for total $E$. coli load and the average of the colonies formed in the three plates was recorded. Total plate count was done by multiplying the colonies on the plate by the dilution factor. The average number of the total plate counts of each dilution was considered as total counts. In order to enumerate the $E$. coli, Levin's EMB media were used for each sample and incubated at room temperature for $48 \mathrm{~h}$. As the $E$. coli was very rare in water and soil, so the author did the work without serial dilution. Density of $E$. coli was estimated by using pour plate techniques. Colonies having a green metallic sheen with dark centre were confirmed as E. coli. The colonies were picked and streaked on the nutrient agar slants and the slants were incubated at room temperature for $48 \mathrm{~h}$. Then the cultures of the slant were subjected to Gram staining, Biochemical test and Fermentation test.

For the isolation of single colony, procedures of Sharp et al. (1969) were followed. The selected colonies were marked and their cultural and morphological characteristics were recorded. Simple correlation have been calculated to depict the relations using the formula:

Coefficient $\mathbf{r}_{x y}=\left(n \sum x y-\sum x \sum y\right) /\left[n \sum x^{2}-\left(\sum x\right)^{2}\right]\left[n \sum y^{2}-\left(\sum y\right)^{2}\right]$

Where, $x=i$ th sample values of one variable $(i=1,2,3 \ldots . . n) ; y=i$ th sample value of other variable; $n=$ total number of samples.

Correlation coefficient has been tested by using the t-test for testing significance or non significance. The formula used is given as follows:

For t-test: $t_{(n-2)}=(r \sqrt{ } n-2) / \sqrt{ }\left(1-r^{2}\right)$

\section{RESULTS}

\section{Hydrographic conditions}

Results from the water samples showed distinct hydrographic conditions (Figure 2). Water temperature varies between 26.5 to $32.0^{\circ} \mathrm{C}$. Maximum water temperature was recorded to be $32.0^{\circ} \mathrm{C}$ in June at St-1 and St-3 while minimum temperature was recorded in March at St-1. Monthly maximum average temperature 


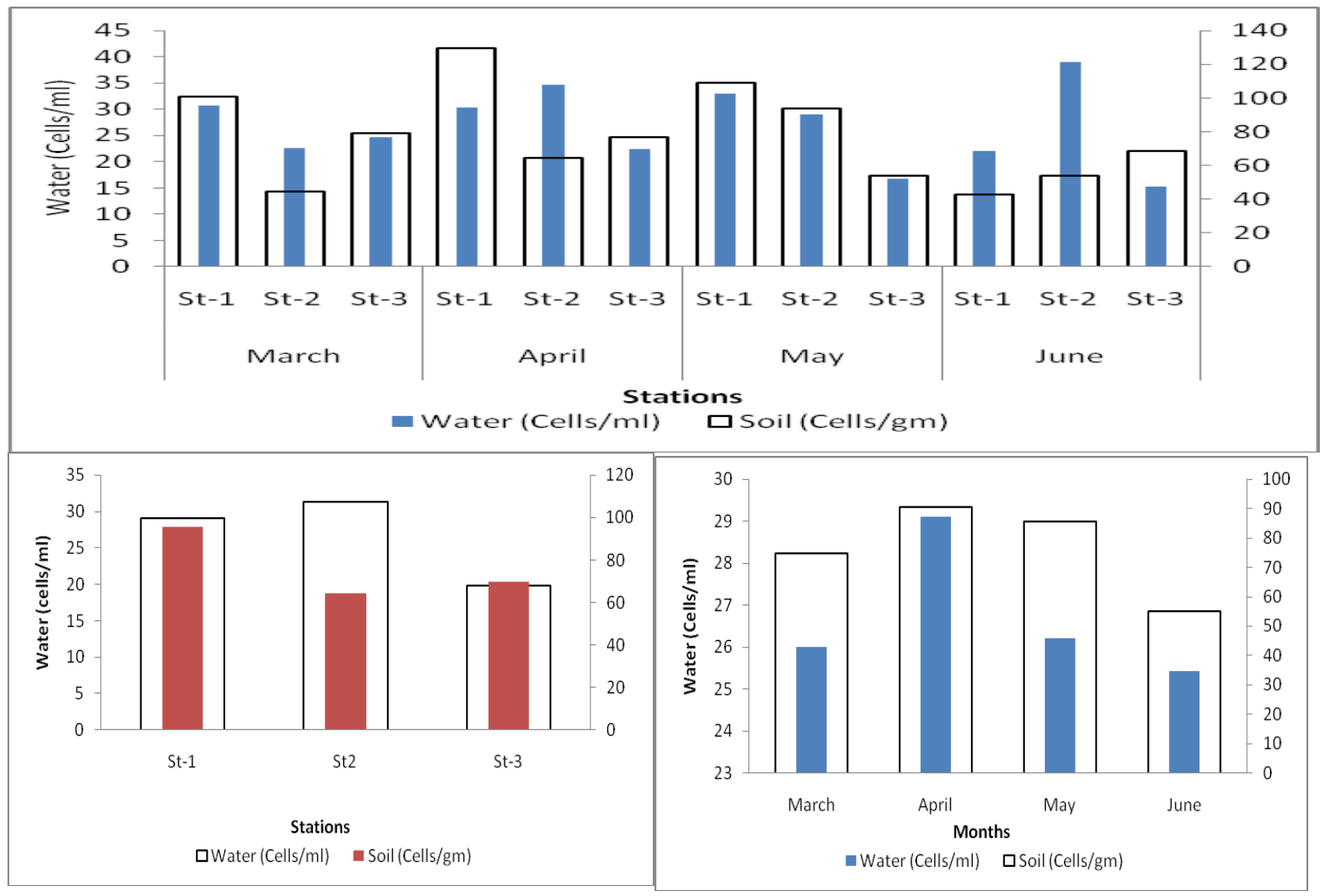

Figure 3. Variation in E. coli concentration in water and soil sample at different stations during different months.

was found to be $31.67^{\circ} \mathrm{C}$ during May while minimum was $26.83^{\circ} \mathrm{C}$ during March. On the other hand, average maximum water temperature was recorded $29.25^{\circ} \mathrm{C}$ at St-2 and St-3 and a minimum of $29.13^{\circ} \mathrm{C}$ at St-1. No significant difference was observed in water temperature among the stations but significant differences were found among the months $(F=23, P<0.01)$. Salinity of the present study was found between $01 \mathrm{ppt}$ to $05 \mathrm{ppt}$. The maximum was recorded (1.6 ppt) in June at St-12 and minimum 0.3 ppt at St-14 during March and April. Monthly maximum average salinity was found as $1.67 \mathrm{ppt}$ during May where minimum salinity was recorded 0.33 ppt during March and April. Mean maximum salinity was observed at 2.3 ppt at St-3 and no salinity was found at St-1 and 2. No significant difference was observed among the stations but there was significant difference among the months $(F=26, P<0.001)$ for salinity value. Dissolved Oxygen (DO) concentration in water sample varies between 2.40 to $2.88 \mathrm{mg} / \mathrm{l}$. The maximum DO content was recorded as 2.91 in July at St-3 and the minimum was recorded in June at St-2. Monthly maximum mean DO was found as $2.71 \mathrm{mg} / \mathrm{l}$ during June and a minimum of $2.02 \mathrm{mg} / \mathrm{l}$ during May. On the other hand, maximum mean DO $2.63 \mathrm{mg} / \mathrm{l}$ was recorded at St-1 while a minimum of $2.25 \mathrm{mg} / \mathrm{l}$ was recorded at St-2. No significant difference was found in
DO among the stations though significant differences were observed among the months $(\mathrm{F}=25, \mathrm{P}<0.01)$. Water $\mathrm{pH}$ varies between 7.5 to 8.5 and maximum $\mathrm{pH}$ value was recorded as 8.5 at St-3, during June and minimum 7.5 during March at St-3. Monthly maximum mean $\mathrm{pH}$ was recorded as 8.13 during May and a minimum of 7.2 during June. Average $\mathrm{pH}$ at maximum level occurred at St-1(7.7) where the minimum was found at St-2 (7.6). No significant difference was found in $\mathrm{pH}$ values among the stations but significant difference was found among the months ( $F=31, P<0.01)$.

\section{E. coli concentration in water and soil samples}

Variation in $E$. coli concentration in water and soil samples at different stations during different months is shown in Figure 3. E. coli counted in water sample was found to contain the highest concentration, 35 cells $/ \mathrm{ml}$ at St-2 during April while minimum concentration was found to be 22 cells $/ \mathrm{ml}$ at St-1 during June. Average maximum concentration of $E$. coli was found to be $29 \mathrm{cell} / \mathrm{s} / \mathrm{ml}$ during April while minimum concentration $25 \mathrm{cells} / \mathrm{ml}$ was found during June. During March and May, concentration of $E$. coli was found to be 26 cells/l. Mean concentration in 


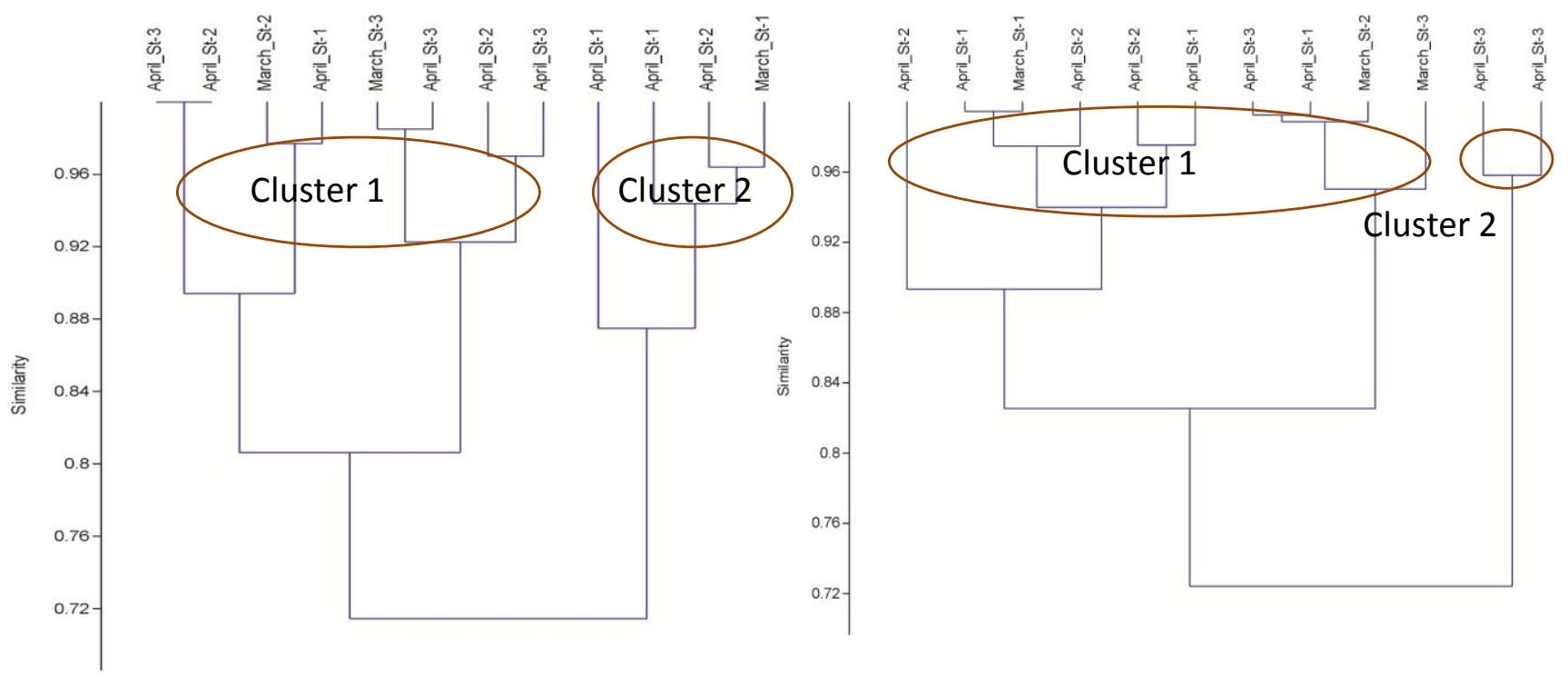

Figure 4. Dendrogram showing the cluster of E. coli occurrence in soil and water sample.

maximum level found 31 cells/l at St-2 and minimum concentration of $20 \mathrm{cells} / \mathrm{l}$ at St-3 where $29 \mathrm{cells} / \mathrm{l}$ was recorded at St-1. E. coli counted in soil sample was found to have the highest concentration, $109 \mathrm{cells} / \mathrm{g}$ at St-1 during May while minimum concentration was found to be 54 cells/g at St-3 during May and St-2 during June. Average maximum concentration of $E$. coli was found to be 90 cells/g during April while minimum concentration was found to be $55 \mathrm{cells} / \mathrm{g}$ in June. During March and May concentration of $E$. coli was found to be 75 and $85 \mathrm{cells} / \mathrm{g}$ respectively. Mean concentration in maximum level was found as 95 cells/g at St-1 and a minimum of 64 cells $/ g$ at St-2 where 70 cells/g was recorded at St-3.

\section{Spatial and temporal similarity of $E$. coli occurrence}

Cluster analysis of $E$. coli concentration in water and soil samples is based on different sampling stations and months as shown in Figure 4. Regarding temporal and spatial assemblage in soil sample two clusters were formed at $72 \%$ similarity level. Cluster 1 consists of April St-2, April St-1, March St-1, April St-3, March St-2 and March St-3 which showed similarity to April St-3. Similar to soil sample, two clusters were also found for soil samples regarding temporal and spatial assemblage of $E$. coli occurrence at $72 \%$ similarity level. Cluster 1 consists of April St-2, April St-3, March St-3 April St-1 which showed similarity with cluster 2 and consists of April St-1, April St-2 and March St-1.

\section{Effects of water parameters on E. coli concentration}

Regression line (Figure 5) has been drawn to see the influence of water parameters on $E$. coli concentration in water sample at Karnafuly River estuary. With the increase of water temperature $E$. coli concentration has increased a little in water sample $(y=0.0237 x+26.003)$ whereas in case of salinity, a decreased trend $(y=-$ $3.2751 x+29.424)$ in occurrence of $E$. coli was found with increased salinity level. On the other hand similar to salinity, a decreased trend was found in $E$. coli concentration in water sample at Karnafuly River estuary with the increase of water $\mathrm{pH}(\mathrm{y}=-5.0745 \mathrm{x}+65.599)$ and Dissolve Oxygen $(y=-1.091 x+29.408)$.

Similar to water sample, regression line (Figure 6) has also been drawn to observe the influence of water parameters on $E$. coli concentration in soil sample. In case of soil sample, similar trend of water sample $E$. coli concentration was found for all parameters. E. coli concentration has increased in soil sample of Karnafuly River estuary with the increase of water temperature $(y=0.8078 x+52.823)$.

On the other hand decreased trend was observed for $E$. coli concentration in soil sample with increase of salinity $(\mathrm{y}=-4.7896 \mathrm{x}+80.41), \mathrm{pH}(\mathrm{y}=-1.9996 \mathrm{x}+91.749)$ and Dissolve oxygen $(y=-4.9654 x+88.766)$ concentration in water.

\section{DISCUSSION}

From the present physicochemical study of the water quality of the Karnafuly, it can be concluded that the condition of the Karnafuly River is critical. Decreasing trend of DO of the Karnafuly River water was observed from the present and previous study (Majid et al., 1977). Minimum DO value found for the Karnafuly River was as 

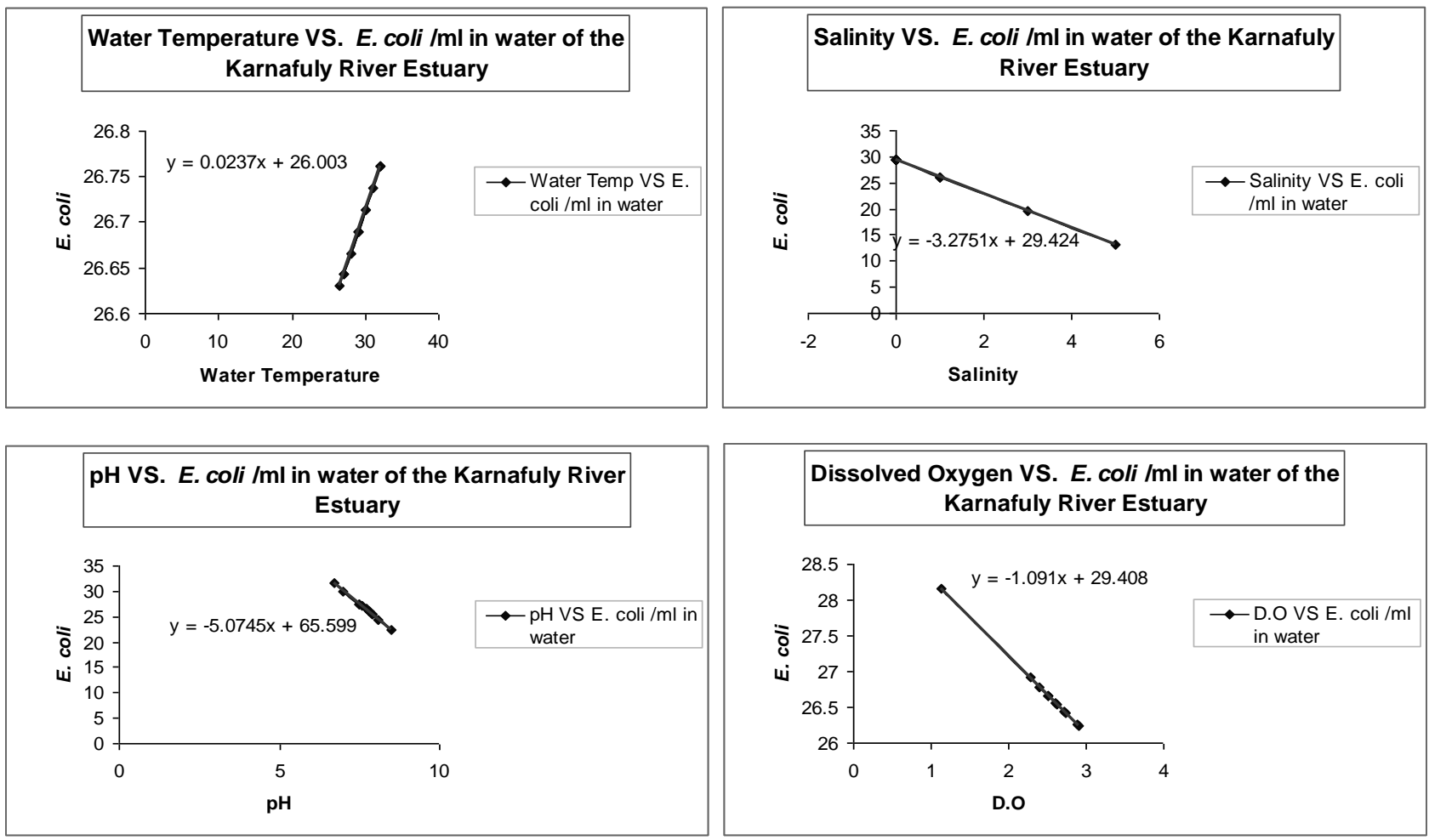

Figure 5. Regression analyses showing the influence of water parameters on E. coli concentration in water sample.

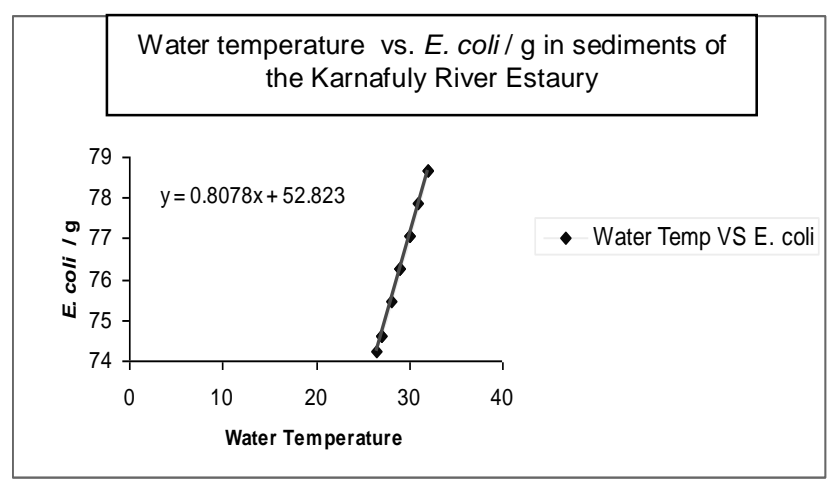

Salinity vs. E. coli / g in sediments of the Karnafuly River Estaury

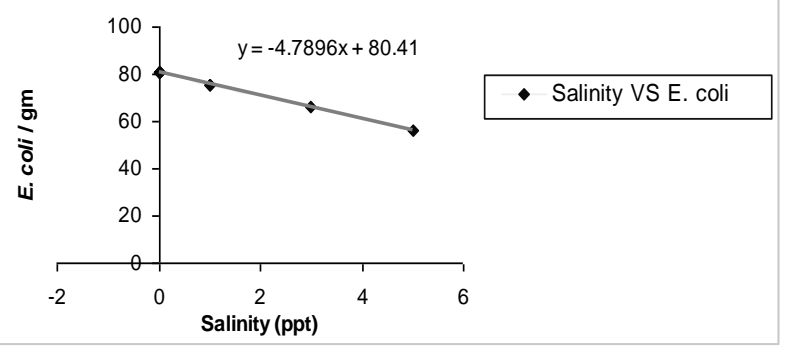

$\mathrm{pH}$ vs. E. coli / g in sediments of the Karnafuly River Estaury

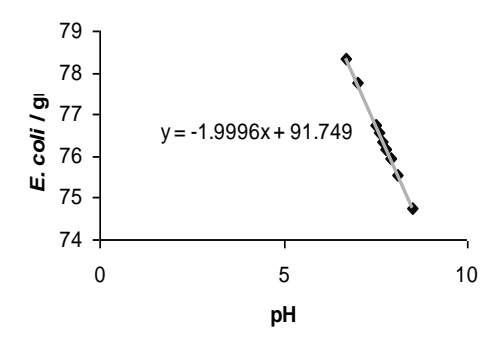

Dissolved Oxygen vs. E. coli / g in sediments of the Karnafuly River Estaury

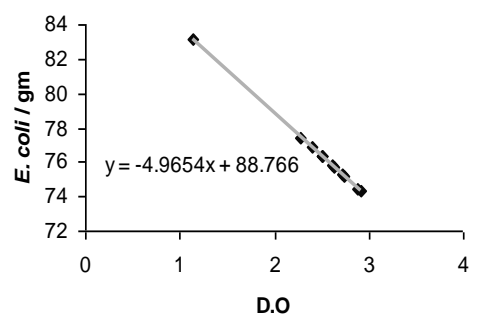

Figure 6. Regression analyses showing the influence of water parameters on E. coli concentration in soil sample. 
low as $2.40 \mathrm{mg} / \mathrm{l}$. This indicates the critical condition of this River. Similar situation was observed by Gasim (2007). Alam et al. (1996) reported DO values in the range (2.74 to $5.12 \mathrm{mg} / \mathrm{l})$ and (3.95 to $5.97 \mathrm{mg} / \mathrm{l}$ ) for river water samples and (3.73 to $5.01 \mathrm{mg} / \mathrm{l})$ and $(5.04$ to $5.49 \mathrm{mg} / \mathrm{l}$ ) for lake water samples in the dry and rainy seasons, respectively. Mean $\mathrm{pH}$ value of the Naf River water was found in the alkaline range. Similar $\mathrm{pH}$ values 7.5 to 8.5 were reported by Chowdhury et al. (2009) for the Naf River, which is almost similar to the present findings. McLusky and Elliot (2004) stated that salinity of an estuary ranged between 0.50 to $35 \mathrm{ppt}$ and Ahammdd (2004) showed the salinity ranged between 14.43 to $25.92 \mathrm{ppt}$; the salinity of the present work was found at a similar value. Alam (1993) also reported variation of water temperature for seasonal change. Kamal (1992) and Zaman (1994) observed that seasonal variation of water temperature ranged between 7.54 and $10^{\circ} \mathrm{C}$. Belaluzzaman (1995) also found $10^{\circ} \mathrm{C}$ water temperature variations at Bangladesh coast. During the present study monthly variation of water temperature was observed.

Several non-point and point sources can contribute to the presence of fecal indicator bacteria $(E$. coli and enterococci) in aquatic systems that can be detrimental to public health such as, humans, agriculture, water run-off, tidal actions, animal traffic, sustained winds, boats, dredging and polluted groundwater and environmental sources such as soil. Toxic metals pollution is predominant in the Karnafuly River water as the toxic metals were included from drainage of domestic waste. A large number of chemical and fertilizer industries have been established since the independence on both the banks of the Karnafuly. Effluents from these industries are reportedly being directly discharged into this river. Huge amount of solid wastes and effluents are discharged through Chaktai, Sundari, Noakhal, Mazirghat, Gupta, Mohesh, Shikalbhaha and Ferighat canals into the Karnafuly River; as a result, pollution of this river is increasing day by day. Leaking and leaching of oil from ships and boats are also polluting the water of the Karnafuly River.

Due to the climate change during flood, soil erosion and land slide increases the suspended solids, metallic and other pollutants. Polluted water and soil create a favorable condition for $E$. coli multiplication. The previous study revealed high concentrations of $E$. coli and total coliforms bacteria in water, soil and mussels from Guion Creek (Yeung-Cheung et al., 2009). 18000 coliforms $/ 100 \mathrm{ml}$ is recorded in the water sample of Karnafuly River estuary near sewage disposal areas (Hossain, 1980), which is far higher than safer levels $(0 / 100 \mathrm{ml})$ for drinking water and greater than 200 cells/100 $\mathrm{ml}$ for bathing recommended by WHO (1982) which is similar to the present study. A study of the seasonal occurrence and distribution of microbial indicators and pathogens were done in the Rhode river of Chesapeake Bay where they found the highest frequency of occurrence of total $E$. coli load in muddy creek, a marsh area receiving pasture land runoff.

The second highest frequency of occurrence of those bacteria was in Coddle creek a populated area and the lowest measurements of those microbial parameters were obtained at stations in the central portion of the river (Carney et al., 1975). A study was done about the presence of pathogenic organisms in the River Ganga (Sinha and Vajpayee, 1972). Soil appear to serve as a hospitable environment for bacterial survival due to the availability of soluble organic matter and nutrients (Jamieson et al., 2005), protection from predators such as protozoa (Decamp and Warren, 2000), and shielding from exposure to UV sunlight (Koirala et al., 2008). The present study found high concentration of $E$. coli in soil. The concentration of $E$. coli from both water and soil increased during rainfall, but the bacterial concentration quickly decreased to the pre-rain levels (Whitman et al., 2006).

The present study found increased concentration of $E$. coli during the starting of the rainy season. Studies about the physiological states of $E$. coli can be affected by various environmental conditions, e.g. temperature, $\mathrm{pH}$, salinity etc (Miller and Litsky, 1976.) An observation was found that the $E$. coli can survive longer in saline medium than in distilled water (Winslow and Falk, 1923) which is similar to present findings. This result is also consistent with previous results which showed that $E$. coli in distilled water, die most rapidly of elevated temperature and high $\mathrm{pH}$ values (Cohen, 1992).

\section{Conclusion}

Water of Karnafuly River estuary used for any purpose, may affect people by several health hazard diseases like diarrhea, dysentery, cholera, typhoid etc. With the relation of some relative physio-chemical parameters against $E$. coli bacteria both in water and soil, it was observed that against temperature, E. coli was insignificantly ( $1 \%$ confidence level) positively correlated whereas negatively correlated against salinity, $\mathrm{pH}$ and DO. In the present work, with comparison between the water and soil, it was found that soil sample carries higher total E. coli load than water sample. It may be 2-3 times more than water in all stations of the Karnafuly River estuary.

In Karnafuly River area, people suffer from various health hazard diseases due to use of water for drinking, bathing, washing and soil for various household purposes. Water and soil resources and fish species of Karnafuly estuary are contaminated by $E$. coli. After the study, it is concluded that $E$. coli bacteria from three stations of the Karnafuly, exceed the standard level both in water and soil, so this water is polluted and unhygienic 
for drinking and even washing without treatment, which directly affects human health.

\section{ACKNOWLEDGEMENTS}

The authors are grateful for the technical lab and instrument support of the Institute of Marine Sciences and Fisheries, University of Chittagong, Bangladesh to complete the research work successfully.

\section{REFERENCES}

Ahmed F (2004) Catch Composition of Estuarine Set Bag Net (ESBN) in the Moheshkhali Channel of the Bay of Bengal, Bangladesh. MSc Thesis, Institute of Marine Sciences, University of Chittagong, Bangladesh.

APHA (1976). Standard methods for examination of water and waste water $\left(14^{\text {th }}\right.$ ed.). American Public Health Association Inc. Washington D.C.

Carney JF, Carty CE, Colwell RR (1975). Seasonal occurrence and distribution of microbial indicators and pathogens in Rhode River of Chesapeake bay. Appl. Microbiol. 30:771-780.

Cohen GF (1992). The effect of ecological factors on bacteria in water. Vern. Inst. Verein. Angeu. Limnol. 17:731-743.

Decamp O, Warren A (2000). Investigation of $E$. coli removal in various designs of subsurface flow wetlands used for wastewater treatment. Ecol. Eng. 14:293-299.

EQSB (1991). Environmental Quality Standard for Bangladesh. Department of Environment, Government of the People's Republic of Bangladesh.

Geldreich EE (1970). Applying bacteriological parameters to recreational water quality. J. Am. Water Works Assoc. 62:113-120.

Hossain MM (1980). Pollution as revealed by macro benthic organisms in the Karnafuly river estuary. M. Sc. Thesis. Institute of Marine Sciences, University of Chittagong, Chittagong, Bangladesh.

Islam MN (1998). Study on the pollution indicating bacteria in the brackish water environment with reference to Karnafuly river estuary. M. Sc. Thesis. Institute of Marine Sciences, University of Chittagong, Chittagong, Bangladesh.
Jamieson RC, Joy DM, Lee H, Kostaschuk R, Gordon RJ (2005). Resuspension of soil-associated Escherichia coli in a natural stream. J. Environ. Qual. 34:581-589.

Joy CM, Bakkrishnan KP, Joseph A (1990). Physicochemical aspects of a tropical river receiving industrial effluents. New Delhi, India. pp. 220-233.

Kim GH, Yur JH, Kim JK (2007). Diffuse pollution loading from urban storm water runoff in Daejeon city, Korea J. Environ. Manag. 85:9-16.

Koirala SR, Gentry RW, Perfect E, Schwartz JS, Sayler GS (2008). Temporal variation and persistence of bacteria in streams. J Environ. Qual. 37:1559-1566.

McLusky DS, Elliott M (2004). The Estuarine Ecosystem. Oxford. Oxford University Press. p. 214.

Miller SK, Litsky BS (1976). Ecological effect of sewage pollution in Biscayne Bay. Florida. In: Soil and micro organisms. Bull. Mar. Sci. 11:364.

Rehmann CR, Soupir MR, (2009). Importance of interactions between the water column and the soil for microbial concentrations in streams. Water Res. 43:4579-4589.

Rizbi SNH (1971). Bangladesh district gazetteers, Chittagong. Govt. of Bangladesh, Service and general administration department. Bangladesh Government Press. Dacca. p. 64.

Sinha AK, Vajpayee SL (1972). Pathogenic organisms in River Ganga between Shuklagonj and Kalkankar. Ashish Publishing House. New Delhi. pp. 207-216.

Whitman RL, Nevers MB, Byappanahalli MN (2006). Examination of the watershed-wide distribution of $E$. coli along southern Lake Michigan an integrated approach. Appl. Environ. Microbiol. 72(11):7301-7310.

WHO (1984). Guidelines for drinking water quality. World Health Organization.

WHO (1993). Microbial specifications for drinking water. World Health Organization. Ecol. Microbiol. p. 173.

Winslow CK, Falk TS (1923). Estuarine oil pollution effect on the micro benthos. Fishing news (Books) Ltd. 23, Rosemount Avenue, West Byfleet Surrey, England. pp. 243-258.

Yeung-Cheung AK, Benevento NM, Pavel DM (2009). An evaluation of the effectiveness of the Gunderboom in protecting waters from bacteria. J. Environ. Health 71(8):42-47. 